\title{
Skill acquisition of safe medication administration through realistic simulation: an integrative review
}

\author{
Aquisição de competências para administração segura de medicamentos por meio da \\ simulação realística: revisão integrativa \\ Adquisición de habilidades para la administración segura de medicamentos a través \\ de simulación realista: revisión integradora
}

Breno de Sousa Santana' ORCID: 0000-0002-4899-5209

Alberto Augusto Martins Paiva' ORCID: 0000-0002-2223-4516

Marcia Cristina da Silva Magro' ORCID: 0000-0002-4566-3217

'Universidade de Brasília. Brasília, Distrito Federal, Brazil.

How to cite this article:

Santana BS, Paiva AAM, Magro MCS. Skills acquisition for safe drug administration through realistic simulation: integrative review.

Rev Bras Enferm. 2020;73(Suppl 5):e20190880. doi: http://dx.doi.org/10.1590/0034-7167-2019-0880

Corresponding author:

Breno de Sousa Santana

E-mail:bresousas@outlook.com

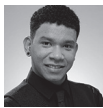

EDITOR IN CHIEF: Dulce Barbosa ASSOCIATE EDITOR: Alexandre Balsanelli

Submission: 03-11-2020

Approval: 06-14-2020

\section{ABSTRACT}

Objective: to investigate evidence that indicates the contribution of realistic high, medium or low fidelity simulation to acquire knowledge, skills and attitudes in safe medication administration by nursing students. Methods: an integrative review of experimental studies from MEDLINE, LILACS, Web of Science, Scopus and Science Direct. The descriptors "nursing students", "simulation", "high fidelity simulation training", "medication errors" and "pharmacology" were used to identify 14 studies that answered the research question, and were assessed for accuracy methodological level and level of evidence. Results: there was a sample of quasi-experimental studies, (level 3 of evidence; $78.6 \%$ ) and randomized clinical trials (level 2 of evidence; $21.4 \%$ ), whose expressive majority showed superiority of the simulation strategy over the traditional methodology (71.4\%). Conclusion: using low and high fidelity simulators, standardized patients and virtual simulation can promote acquisition of essential skills for patient safety.

Descriptors: Simulation Training; Conduct of Drug Treatment; Patient Safety; Learning; Nursing Education.

\section{RESUMO}

Objetivo: investigar as evidências que indiquem a contribuição da simulação realística de alta, média ou baixa fidelidade para aquisição de conhecimentos, habilidades e atitudes na administração segura de medicamentos por estudantes de enfermagem. Métodos: revisão integrativa de estudos experimentais das bases de dados MEDLINE, LILACS, Web of Science, Scopus e Science Direct. Utilizaram-se os descritores "estudantes de enfermagem", "simulação", "treinamento por simulação de alta fidelidade", "erros de medicação" e "farmacologia" para identificar 14 estudos que respondiam à questão de pesquisa, e foram avaliados quanto ao rigor metodológico e nível de evidência. Resultados: amostra de estudos quase-experimentais, (nível 3 de evidência; 78,6\%) e ensaios clínicos randomizados (nível 2 de evidência; 21,4\%), cuja expressiva maioria evidenciou superioridade da estratégia de simulação em relação à metodologia tradicional $(71,4 \%)$. Conclusão: o uso de simuladores de baixa e alta fidelidade, pacientes padronizados e simulação virtual pode promover ganho de competências essenciais para a segurança do paciente.

Descritores: Treinamento por Simulação; Conduta do Tratamento Medicamentoso; Segurança do Paciente; Aprendizagem; Educação em Enfermagem.

\section{RESUMEN}

Objetivo: investigar evidencia que indique la contribución de la simulación de alta, media o baja fidelidad a la adquisición de conocimientos, habilidades y actitudes en la administración de medicamentos por parte de estudiantes de enfermería. Métodos: revisión integradora de estudios experimentales de las bases MEDLINE, LILACS, Web of Science, Scopus y Science Direct. Los descriptores "estudiantes de enfermería", "simulación","capacitación en simulación de alta fidelidad", "errores de medicación" y "farmacología" foran utilizados para identificar 14 estudios que respondieron a la pregunta de investigación. Resultados: una muestra de estudios cuasiexperimentales (nivel 3 de evidencia; $78.6 \%$ ) y ensayos clínicos aleatorizados (nivel 2 de evidencia; $21.4 \%$ ), cuya mayoría expresiva mostró superioridad de la estrategia de simulación en relación con la metodología tradicional (71,4\%). Conclusión: el uso de simuladores de baja y alta fidelidad, pacientes estandarizados y simulación virtual puede promover la adquisición de habilidades esenciales para la seguridad del paciente. Descriptores: Entrenamiento Simulado; Administración del Tratamiento Farmacológico; Seguridad del Paciente; Educación en Enfermería. 


\section{INTRODUCTION}

Despite the advances made in the health care scenario, high rates of medication errors in clinical practice ${ }^{(1)}$ and difficulties in implementing strategies to promote patient safety ${ }^{(2)}$ still constitute a reality. Educational and integrative strategies during professional training can be the differential in safe work exercise.

Health care is often linked to the need for medication, especially among hospitalized patients, and it is up to nursing professionals, above all, the crucial stage of administration ${ }^{(3)}$. Medication administration is an action that requires health professionals to have psychomotor skills, clinical reasoning and decision-making and its success directly affects the quality and safety of patient care( ${ }^{(4)}$.

In this context, the quality of practical professional performance, since it is not free from errors, can have an impact on patient safety ${ }^{(5)}$. Medication errors (ME), although preventable, constitute a global concern in health care scenario, with a potential impact on hospital stay, recovery and mortality rates of patients ${ }^{(3)}$.

Commonly, undergraduate nursing curricula are anchored in traditional teaching, when professors are content transmitters and students are assigned the passive role of memorizing information, without co-responsibility for what must be learned ${ }^{(6)}$. Such fact limits the transposition of knowledge acquired in the classroom to real practice and predisposes occurrence of errors ${ }^{(7)}$. This scenario can be aggravated due to the limited offer of internships or practice environments that generate learning opportunities with real patients ${ }^{(8)}$.

Active methodologies represent, in this context, a potential alternative, capable of including students as co-participants in the teaching-learning process ${ }^{(9-11)}$. The realistic simulation strategy stands out for promoting a safe environment for acquisition and improvement of knowledge, skills and attitudes through reproducing clinical environments close to the real one ${ }^{(12)}$.

Although the benefits of simulation in several educational contexts are already known ${ }^{(13-14)}$, including the promotion of skills related to the medication process ${ }^{(15-16)}$, it is necessary to revisit scientific literature to understand the level of current knowledge and list what are the future paths to be taken in teaching safe nursing care.

\section{OBJECTIVE}

To investigate evidence that indicates the contribution of realistic high, medium or low fidelity simulation to acquire knowledge, skills and attitudes in safe medication administration.

\section{METHODS}

\section{Ethical aspects}

This research was not submitted to an ethics committee, as it is an integrative review. However, the authors' original ideas of the studies used to prepare this study were maintained.

\section{Study design}

This is an integrative literature review, a design that allows synthesis of findings in the primary studies on a phenomenon under investigation. Developing this review was structured in six stages: 1 ) creation of the research question; 2) definition of databases and criteria for inclusion and exclusion of studies; 3 ) definition of the information to be extracted from the selected studies; 4) assessment of the included studies; 5 ) interpretation of results; 6) presentation of the knowledge synthesis ${ }^{(17)}$.

To construct the research question, the PICO strategy was used $^{(18)}$. PICO stands for population (undergraduate nursing students); intervention (low, medium and/or high fidelity simulation); comparison (traditional teaching strategy); and outcome (knowledge, skills or attitudes in safe medication administration). Thus, this review was guided by the following question: what is the contribution of realistic low, medium or high fidelity simulation in the learning process related to safe medication administration, when compared to the traditional teaching methodology for undergraduate nursing students?

In this study, we consider traditional strategy, one in which the professor is the active subject in the teaching-learning process and passes on knowledge in a narrative way to students, listeners, who must memorize, repeat and fix the content. Within the scope of traditional teaching, expository classes, lectures, didactic handouts, resolution of model exercises with fictional problems based on content presented by professors as well as others in which students are passive in knowledge building $(7,19-20)$.

Bibliographic search was carried out at Latin American \& Caribbean Literature in Health Sciences (LILACS) through the Virtual Health Library (VHL) portal; Medical Literature Analysis and Retrieval System Online (MEDLINE) through the PubMed portal; Scopus; Elsevier's Web of Science and Science Direct.

\section{Inclusion and exclusion criteria}

Original articles, published in the last 10 years (2010-2019) in Brazilian Portuguese, English, and Spanish, whose sample was composed of nursing students, which addressed training, qualification and/or other strategies that promote the development of knowledge, skills and competencies related to safe medication administration by low, medium or high fidelity simulation have been included. Studies whose emphasis on the description of medication administration was the pediatric, neonatal or obstetric public, duplicate, review articles and those that did not answer the research question have been excluded.

After selection, the titles and abstracts eligible in the search were analyzed independently by two researchers. They, at the end of eligibility, met to assess the convergences and reduce disagreements in selection, thus selecting the articles included in the review.

\section{Collection and organization of data}

To systematize the search, the following Health Sciences Descriptors (Descritores em Ciências da Saúde - DeCS) (in Brazilian Portuguese) were listed as well as the Spanish and English equivalents (Medical Subject Headings - MeSH):"Nursing Students", "Simulation","High Fidelity Simulation Training," "Medication Errors", and "Pharmacology". From the descriptors, uncontrolled terms from the DeCS and MeSH synonyms list were also included (Chart 1). 
Chart 1 - Description of PICO strategy to create the research question, selection of descriptors and uncontrolled terms used in searching the primary studies. Brasília, Federal District, Brazil, 2019

\begin{tabular}{|c|c|c|}
\hline & $\begin{array}{l}\text { Terms listed by the } \\
\text { acronym PICO }\end{array}$ & $\begin{array}{l}\text { Uncontrolled descriptors and } \\
\text { terms }\end{array}$ \\
\hline $\mathbf{P}$ & $\begin{array}{l}\text { Nursing undergraduate } \\
\text { students }\end{array}$ & $\begin{array}{l}\text { Estudantes de Enfermagem; } \\
\text { Estudiantes de Enfermería; Nursing } \\
\text { Student; Nursing Students; } \\
\text { Baccalaureate Nursing Education; } \\
\text { Baccalaureate Nursing Educations. }\end{array}$ \\
\hline I & $\begin{array}{l}\text { High, medium or low } \\
\text { fidelity simulation }\end{array}$ & $\begin{array}{l}\text { Simulação; Simulación; Simulation; } \\
\text { Treinamento com Simulação de Alta } \\
\text { Fidelidade; Enseñanza Mediante } \\
\text { Simulación de Alta Fidelidad; High } \\
\text { Fidelity Simulation Training. }\end{array}$ \\
\hline C & $\begin{array}{l}\text { Traditional teaching } \\
\text { methodologies }\end{array}$ & -- \\
\hline 0 & $\begin{array}{l}\text { Knowledge, skills } \\
\text { and attitudes for safe } \\
\text { medication administration }\end{array}$ & $\begin{array}{l}\text { Medicação; Medicación; Medication; } \\
\text { Erros de Medicação; Errores de } \\
\text { Medicación; Medication Errors; } \\
\text { Farmacologia; Farmacología; } \\
\text { Pharmacology; Pharmacologies }\end{array}$ \\
\hline
\end{tabular}

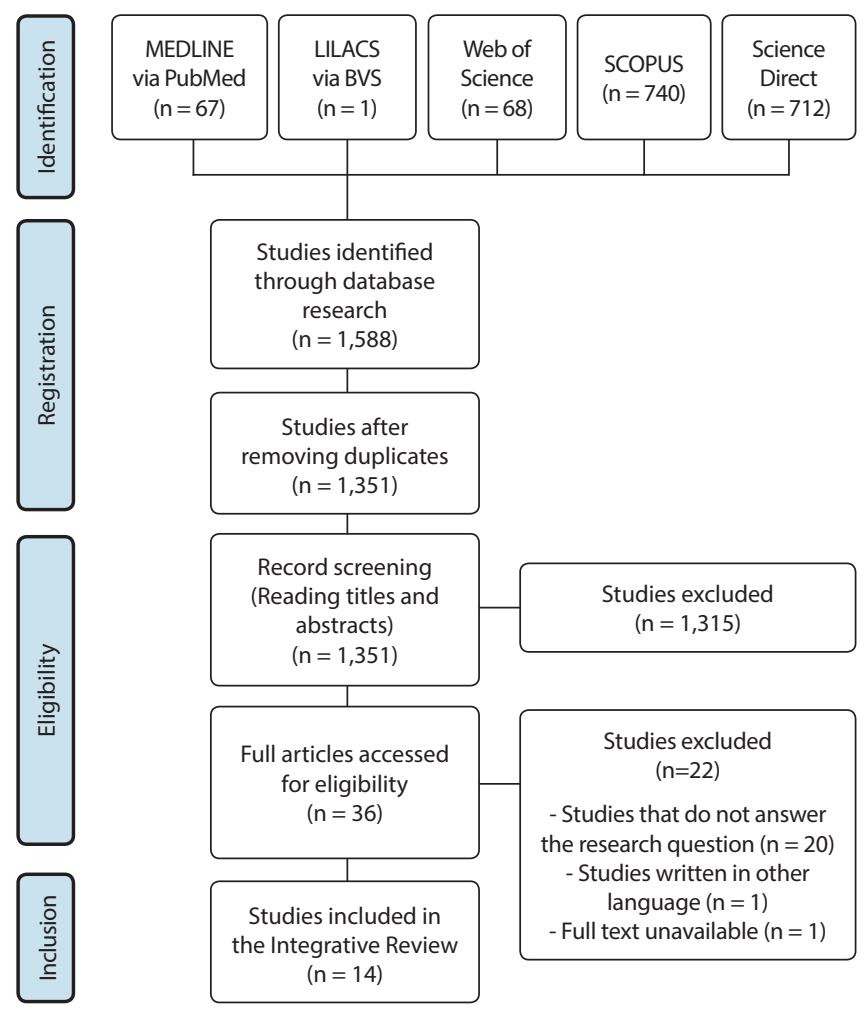

Figure 1 - Flowchart of identification, registration, eligibility and inclusion of studies in the Integrative Review. Brasília, Federal District, Brazil, 2019

From the descriptors and uncontrolled terms, the following search strategy was conducted in Brazilian Portuguese and Spanish at LILACS database: ("Estudantes de Enfermagem" OR"Estudiantes de Enfermería") AND (Simulação OR Simulación OR "Treinamento com Simulação de Alta Fidelidade"OR"Enseñanza Mediante Simulación de Alta Fidelidad") AND (Medicação OR Medicación OR"Erros de Medicação"OR"Errores de Medicación" OR Farmacologia OR Farmacología). At other databases, the search strategy in English was carried out as follows: ("Nursing Student"OR"Nursing Students"OR"Baccalaureate
Nursing Education" OR "Baccalaureate Nursing Educations") AND (Simulation OR "High Fidelity Simulation Training") AND (Medication OR"Medication Errors"OR Pharmacology OR Pharmacologies).

In July 2019, the search was conducted, which resulted in 67 studies at MEDLINE; 740 studies at SCOPUS; 68 studies at Web of Science; 1 study at LILACS; and 712 studies at Science Direct, totaling 1,588 primary studies. The references were exported to the EndNoteWeb ${ }^{\circ}$ manager, where 237 studies were automatically duplicated and later checked by the researcher. With the aid of Rayyan', titles and abstracts were read in pairs. Inclusion and exclusion criteria were applied to determine which studies would be eligible to build the review, with 36 articles selected, which were read in full. Of these, 14 articles were included in this integrative review and 22 articles were excluded for the reasons described in Figure 1.

\section{Analysis of data}

Gathering information from the primary studies was guided by a structured data collection instrument developed by the authors and assessed by professors of a Graduate Program in Nursing. In this way, a spreadsheet was created in Microsoft Office Excel $365^{\circ}$ with the following items: article title, authors, year of publication, journal of publication, country of publication; study objective; study design; level of evidence; methodological quality; sample; description of the interventions adopted; scenario fidelity; route of administration studied; resources used in simulation; scales and instruments adopted to measure outcomes; main results; main limitations; study conclusions and recommendations for future studies.

The level of evidence assessment followed a hierarchical classification, being: level 1 - systematic reviews of randomized studies; level 2 - individual randomized clinical trial; level 3 - cohort study or non-randomized experimental study; level 4 - case-control study, case series or controlled historical studies; level 5 - qualitative studies ${ }^{(21)}$.

The methodological quality of the included primary studies was assessed with the aid of Simulation Research Evaluation Rubric (SRR). SRR classifies the quality of a published article according to 14 to 16 categories, namely: introduction; history; background; literature review; problem statement, study objective, research question; guiding theory or conceptual framework; study design; study design strength (quantitative or qualitative); sample and study configuration; simulation development; simulation implementation description; description of feedback or debriefing; study instruments (quantitative or qualitative); results; discussion and report of approval by the Institutional Review Board or Research Ethics Committee ${ }^{(22)}$.

When using the SRR to assess the primary studies, it was considered whether the study was a mixed method, only quantitative or only qualitative. When it came to a study of mixed methods, all 16 categories were assessed. When the study was a single method (qualitative or quantitative), only one method was used, classified into 14 categories. The SRR has a rating scale of 5 points, ranging from 0 to 4 , where 0 = unsatisfactory; 1 = bad; 2 = good; $3=$ very good; $4=$ excellent. Scores can vary from 0 to 64 for mixed method studies and from 0 to 56 points for single method studies and are 
converted into percentages, so that the final classification, based on the percentage score, is as follows: excellent ( $76 \%$ to $100 \%)$, good (50\% to $75 \%$ ), regular ( $26 \%$ to $49 \%$ ) and weak $(0 \% \text { to } 25 \%)^{(22-23)}$. The results of this study are presented in a descriptive format and discussed based on scientific literature.

Analysis of the selected studies, in relation to the research design, was based on the literature ${ }^{(17-18,22)}$. Data analysis and synthesis were extracted from the articles performed in a descriptive manner, which made it possible to observe, describe and classify the data, in order to gather the knowledge produced on the topic explored in the review.

\section{RESULTS}

The sample of this review was composed of 14 primary studies published mainly in English $(n=13 ; 92.9 \%)$, with the exception of one study published in Brazilian Portuguese (7.1\%). The studies were carried out between 2013 and 2019 , concentrated mainly in 2018 ( $n=4 ; 28.6 \%)$ and from the United States ( $n=9 ; 64.3 \%)$, Turkey $(n=2 ; 14.3 \%)$, Israel $(n=2 ; 14.3 \%)$, and Brazil $(n=1 ; 7.1 \%)$. Teaching and Learning in Nursing was the most prominent journal $(n=4 ; 28.6 \%)$ according to the data presented in Chart 2 .

Quasi-experimental studies, level 3 in the evidence hierarchy ( $n=11 ; 78.6 \%)$, prevailed, followed by randomized clinical trials, level 2 in the hierarchical classification of evidence $(n=3$; $21.4 \%$ ). All studies were quantitative in nature and $21.4 \%$ used only descriptive statistics ${ }^{(25,30,34)}$. By applying the SRR, which ranges from 0 to 56 points in purely quantitative studies, there was a distribution of the quality from good $(n=8 ; 57.1 \%)$ to excellent ( $n=6 ; 42.9 \%$ ), varying between 31 and 54 points, corresponding to $55.35 \%$ to $96.42 \%$ in methodological quality (Chart 3).

The primary studies included described in the simulation proposal the priority use of standardized patients (role play) (42.8\%) and high fidelity mannequins (35.7\%). No use of medium fidelity mannequins has been reported. In addition, the predominant content of the studies covered high fidelity scenarios (50.0\%) and oral (42.8\%), intravenous (35.7\%), and subcutaneous (35.7\%) routes of administration. A considerable part of the sample did not specify the learning resources used in simulation $(28.6 \%)$, the degree of fidelity (35.7\%) and the administration route adopted in the scenarios (21.4\%). It is worth mentioning that each study may have presented more than one characteristic among those described in Table 1.
Chart 2 - Characterization of the primary studies included in the sample ( $n=14)$. Brasília, Federal District, Brazil, 2019

\begin{tabular}{|c|c|c|c|c|}
\hline Title & Authors & Year & Journal & Country \\
\hline $\begin{array}{l}\text { Transferability of Medication } \\
\text { Administration Simulation Training } \\
\text { to Clinical Settings } \\
(24)\end{array}$ & $\begin{array}{l}\text { Rinat Avraham, Vlada } \\
\text { Shor, Nancy Hurvitz, } \\
\text { Rachel Shvartsur, Einat } \\
\text { Kimhi }\end{array}$ & 2018 & $\begin{array}{l}\text { Teaching } \\
\text { and Learning } \\
\text { in Nursing }\end{array}$ & Israel \\
\hline $\begin{array}{l}\text { Impact of simulation on safe } \\
\text { medication practice with diploma/ } \\
\text { ADN students }{ }^{(25)}\end{array}$ & Carol A. Campbell & 2013 & $\begin{array}{l}\text { Teaching } \\
\text { and Learning } \\
\text { in Nursing }\end{array}$ & USA \\
\hline $\begin{array}{l}\text { Now I know how! The learning } \\
\text { process of medication } \\
\text { administration among nursing } \\
\text { students with non-immersive } \\
\text { desktop virtual reality simulation }{ }^{(26)}\end{array}$ & $\begin{array}{l}\text { Ilana Dubovi, Sharona } \\
\text { T. Levy, Efrat Dagan }\end{array}$ & 2017 & $\begin{array}{l}\text { Computers \& } \\
\text { Education }\end{array}$ & Israel \\
\hline $\begin{array}{l}\text { Using simulation to improve the } \\
\text { medication administration skills of } \\
\text { undergraduate nursing students }{ }^{(27)}\end{array}$ & $\begin{array}{l}\text { Margaret A. Harris, } \\
\text { Laura Pittiglio, Sarah E. } \\
\text { Newton, Gary Moore }\end{array}$ & 2014 & $\begin{array}{l}\text { Nursing } \\
\text { Education } \\
\text { Perspectives }\end{array}$ & USA \\
\hline $\begin{array}{l}\text { Effect of Simulation on } \\
\text { Nursing Students' Medication } \\
\text { Administration Competence }{ }^{(28)}\end{array}$ & $\begin{array}{l}\text { Melissa Jarvill, Sheryl } \\
\text { Jenkins, Olcay Akman, } \\
\text { Kim Schafer Astroth, } \\
\text { Carla Pohl, Peggy J. } \\
\text { Jacobs }\end{array}$ & 2018 & $\begin{array}{l}\text { Clinical } \\
\text { Simulation in } \\
\text { Nursing }\end{array}$ & USA \\
\hline $\begin{array}{l}\text { An Advanced Medication } \\
\text { Administration Experience to } \\
\text { Promote Students' Knowledge } \\
\text { Acquisition in the Skill of } \\
\text { Administering Medications }{ }^{(29)}\end{array}$ & $\begin{array}{l}\text { Susan H. Kelly, Linda } \\
\text { Koharchik, Rosanna } \\
\text { Henry, Marie Cippel, } \\
\text { Susan Hardner, Amber } \\
\text { Kolesar, Bernadette } \\
\text { Clark }\end{array}$ & 2018 & $\begin{array}{l}\text { Teaching } \\
\text { and Learning } \\
\text { in Nursing }\end{array}$ & USA \\
\hline $\begin{array}{l}\text { Using High fidelity Simulation } \\
\text { to Increase Nursing Student } \\
\text { Knowledge in Medication } \\
\text { Administration }^{(30)}\end{array}$ & Leona Konieczny & 2016 & $\begin{array}{l}\text { Teaching } \\
\text { and Learning } \\
\text { in Nursing }\end{array}$ & USA \\
\hline $\begin{array}{l}\text { Medication Safety Simulation to } \\
\text { Assess Student Knowledge and } \\
\text { Competence }{ }^{(31)}\end{array}$ & $\begin{array}{l}\text { Bette Mariani, Jennifer } \\
\text { Gunberg Ross, Susan } \\
\text { Paparella, Lois Ryan } \\
\text { Allen }\end{array}$ & 2017 & $\begin{array}{l}\text { Clinical } \\
\text { Simulation in } \\
\text { Nursing }\end{array}$ & USA \\
\hline $\begin{array}{l}\text { Simulação realística: método } \\
\text { de melhoria de conhecimento e } \\
\text { autoconfiança de estudantes de } \\
\text { enfermagem na administração de } \\
\text { medicamento }\end{array}$ & $\begin{array}{l}\text { Mayara Silva do } \\
\text { Nascimento, Marcia } \\
\text { Cristina da Silva Magro }\end{array}$ & 2018 & $\begin{array}{l}\text { REME Revista } \\
\text { Mineira de } \\
\text { Enfermagem }\end{array}$ & Brazil \\
\hline $\begin{array}{l}\text { Use of simulation from high fidelity } \\
\text { to low fidelity in teaching of safe- } \\
\text { medication practices }\end{array}$ & $\begin{array}{l}\text { Zehra Kan Onturk, Esra } \\
\text { Ugur, Vildan Kocatepe, } \\
\text { Elif Ates, Nermin } \\
\text { Ocaktan, Vesile Unver, } \\
\text { Ukke Karabacak }\end{array}$ & 2019 & $\begin{array}{l}\text { Journal of } \\
\text { the Pakistan } \\
\text { Medical } \\
\text { Association }\end{array}$ & Turkey \\
\hline $\begin{array}{l}\text { The effect of simulation training } \\
\text { on baccalaureate nursing students' } \\
\text { competency in performing } \\
\text { intramuscular injection }^{(34)}\end{array}$ & Jennifer Gunberg Ross & 2015 & $\begin{array}{l}\text { Nursing } \\
\text { Education } \\
\text { Perspectives }\end{array}$ & USA \\
\hline $\begin{array}{l}\text { Impact of Simulation-Enhanced } \\
\text { Pharmacology Education in } \\
\text { Prelicensure Nursing Education }\end{array}$ & $\begin{array}{l}\text { Jill Steiner Sanko, Mary } \\
\text { Mckay }\end{array}$ & 2017 & $\begin{array}{l}\text { Nurse } \\
\text { Educator }\end{array}$ & USA \\
\hline $\begin{array}{l}\text { Using standardized patients } \\
\text { in nursing education: } \text { Effects } \\
\text { on students' psychomotor skill } \\
\text { development }{ }^{(36)}\end{array}$ & $\begin{array}{l}\text { Senay Sarmasoglu, } \\
\text { Leyla Dinç, Melih Elçin }\end{array}$ & 2016 & $\begin{array}{l}\text { Nurse } \\
\text { Educator }\end{array}$ & Turkey \\
\hline $\begin{array}{l}\text { Home care simulation for student } \\
\text { nurses: Medication management } \\
\text { in the home } \mathrm{e}^{(37)}\end{array}$ & $\begin{array}{l}\text { Diana R. Mager, } \\
\text { Suzanne Hetzel } \\
\text { Campbell }\end{array}$ & 2013 & $\begin{array}{l}\text { Nurse } \\
\text { Education } \\
\text { Today }\end{array}$ & USA \\
\hline
\end{tabular}


Chart 3 - Description of the main results obtained by the primary studies included in the sample $(n=14)$. Brasilia, Federal District, Brazil, 2019

\begin{tabular}{|c|c|c|c|}
\hline Title & Objective & $\begin{array}{l}\text { Outlining/Level of } \\
\text { Evidence/SRR }\end{array}$ & Main results \\
\hline $\begin{array}{l}\text { Transferability of Medication } \\
\text { Administration Simulation } \\
\text { Training to Clinical Settings } s^{(24)}\end{array}$ & $\begin{array}{l}\text { To assess the use of individual } \\
\text { simulation to prepare nursing } \\
\text { students to administer } \\
\text { medication to patients in a } \\
\text { clinical setting. }\end{array}$ & $\begin{array}{l}\text { Prospective quasi- } \\
\text { experimental study with } \\
\text { comparison group } \\
\text { Level } 3 \\
\text { SRR }=50(89.28 \%)\end{array}$ & $\begin{array}{l}\text { Students who participated in simulation reported greater } \\
\text { preparation }(p=0.002) \text { and demonstrated psychomotor } \\
\text { skills }(p=0.04) \text { and critical thinking ( } p=0.03 \text { in relation to } \\
\text { students who did not simulate. Knowledge was similar } \\
\text { between groups }(p=0.51) \text {. }\end{array}$ \\
\hline $\begin{array}{l}\text { Impact of simulation on safe } \\
\text { medication practice with } \\
\text { diploma/ADN students }\end{array}$ & $\begin{array}{l}\text { To examine the effect of } \\
\text { simulation on safe medication } \\
\text { practice for nursing students. }\end{array}$ & $\begin{array}{l}\text { Quasi-experimental } \\
\text { study with comparison } \\
\text { group } \\
\text { Level } 3 \\
\text { SRR }=52(92.85 \%)\end{array}$ & $\begin{array}{l}\text { Experimental group students (simulation) were more } \\
\text { satisfied and confident with the development of skills, and } \\
\text { obtained the necessary knowledge from simulating safe } \\
\text { medication administration in the clinical area. Performance } \\
\text { ratings were mixed between the control (traditional } \\
\text { education) and experimental groups. }\end{array}$ \\
\hline $\begin{array}{l}\text { Now I know how! The learning } \\
\text { process of medication } \\
\text { administration among } \\
\text { nursing students with non- } \\
\text { immersive desktop virtual } \\
\text { reality simulation }{ }^{(26)}\end{array}$ & $\begin{array}{l}\text { To assess the effectiveness of } \\
\text { the PILL-VR simulation "Virtual } \\
\text { Reality of Interleaved Learning in } \\
\text { Pharmacology" as a large-scale } \\
\text { teaching strategy for medication } \\
\text { administration among nursing } \\
\text { students. }\end{array}$ & $\begin{array}{l}\text { Quasi-experimental } \\
\text { study with comparison } \\
\text { group } \\
\text { Level } 3 \\
\text { SRR }=50(89.28 \%)\end{array}$ & $\begin{array}{l}\text { After simulation, the experimental group (virtual } \\
\text { simulation) obtained significantly higher scores near } \\
\text { the } 100 \% \text { ceiling, while the control group (normative } \\
\text { curriculum based on lectures) did not improve their overall } \\
\text { performance for medication administration }(p<0.001) \text {. }\end{array}$ \\
\hline $\begin{array}{l}\text { Using simulation to improve } \\
\text { the medication administration } \\
\text { skills of undergraduate } \\
\text { nursing students }\end{array}$ & $\begin{array}{l}\text { To examine simulation methods } \\
\text { to improve medication } \\
\text { calculation and administration } \\
\text { skills for nursing students. }\end{array}$ & $\begin{array}{l}\text { Quasi-experimental } \\
\text { pilot study without } \\
\text { comparison group } \\
\text { Level } 3 \\
\text { SRR }=40(71.42 \%)\end{array}$ & $\begin{array}{l}\text { The scores for the medication administration exam in the } \\
\text { experimental group (simulation) were significantly higher } \\
\text { than the scores in the control group (traditional education) } \\
\text { ( } p=0.004 \text { ). }\end{array}$ \\
\hline $\begin{array}{l}\text { Effect of Simulation } \\
\text { on Nursing Students' } \\
\text { Medication Administration } \\
\text { Competence }^{(28)}\end{array}$ & $\begin{array}{l}\text { To examine the effect of } \\
\text { an individual simulation } \\
\text { experience (ISE) on medication } \\
\text { administration competency in } \\
\text { nursing students. }\end{array}$ & $\begin{array}{l}\text { Randomized controlled } \\
\text { clinical trial } \\
\text { Level } 2 \\
\text { SRR }=46(82.14 \%)\end{array}$ & $\begin{array}{l}\text { Experimental group students (simulation) obtained } \\
\text { significantly higher scores in the post-test than control } \\
\text { group students (traditional practice) }(p=0.00) \text {, showing } \\
\text { superior competence for medication administration. }\end{array}$ \\
\hline $\begin{array}{l}\text { An Advanced Medication } \\
\text { Administration Experience to } \\
\text { Promote Students' Knowledge } \\
\text { Acquisition in the Skill of } \\
\text { Administering Medications }{ }^{(29)}\end{array}$ & $\begin{array}{l}\text { To verify whether an advanced } \\
\text { simulation improves student } \\
\text { performance for administering } \\
\text { medications in the surgical } \\
\text { medical examination. }\end{array}$ & $\begin{array}{l}\text { Quasi-experimental } \\
\text { study with comparison } \\
\text { group } \\
\text { Level } 3 \\
\text { SRR }=44(78.57 \%)\end{array}$ & $\begin{array}{l}\text { Students who participated in the intervention (simulation) } \\
\text { demonstrated significantly higher aggregate scores in the } \\
\text { medication administration section, in addition to showing } \\
\text { higher confidence in their ability to administer medications } \\
\text { at the bedside, and demonstrated that they would be able } \\
\text { to link the simulation experience in service patient. }\end{array}$ \\
\hline $\begin{array}{l}\text { Using High fidelity Simulation } \\
\text { to Increase Nursing Student } \\
\text { Knowledge in Medication } \\
\text { Administration }^{(30)}\end{array}$ & $\begin{array}{l}\text { To compare high and low fidelity } \\
\text { simulation in nursing students' } \\
\text { pharmacological knowledge. }\end{array}$ & $\begin{array}{l}\begin{array}{l}\text { Randomized controlled } \\
\text { clinical trial }\end{array} \\
\text { Level } 2 \\
\text { SRR }=35(62.5 \%)\end{array}$ & $\begin{array}{l}\text { In the pre-test, both groups had an average score of } 5 \\
\text { out of } 10 . \text { In the post-test, the high fidelity simulation } \\
\text { group scored } 8.15 \text { out of } 10 \text {, higher than the low fidelity } \\
\text { simulation group, which scored } 7.02 \text { out of } 10 \text {. The scores } \\
\text { demonstrate that high fidelity simulation increases } \\
\text { students'knowledge related to medication administration. }\end{array}$ \\
\hline $\begin{array}{l}\text { Medication Safety Simulation } \\
\text { to Assess Student Knowledge } \\
\text { and Competence }{ }^{(31)}\end{array}$ & $\begin{array}{l}\text { To investigate the effect of a } \\
\text { simulation learning experience } \\
\text { on safety in medication } \\
\text { administration. }\end{array}$ & $\begin{array}{l}\begin{array}{l}\text { Randomized controlled } \\
\text { clinical trial }\end{array} \\
\text { Level } 2 \\
\text { SRR }=54(96.42 \%)\end{array}$ & $\begin{array}{l}\text { After simulation, the experimental group (usual and } \\
\text { additional simulation) showed knowledge ( } p=0.02 \text { ) } \\
\text { and competence ( } p=0.028 \text { ) superior for medication } \\
\text { administration than the control group (usual simulation). }\end{array}$ \\
\hline $\begin{array}{l}\text { Simulação realística: método } \\
\text { de melhoria de conhecimento } \\
\text { e autoconfiança de } \\
\text { estudantes de enfermagem } \\
\text { na administração de } \\
\text { medicamento } 32)\end{array}$ & $\begin{array}{l}\text { To identify whether the use of } \\
\text { realistic simulation interferes } \\
\text { with the acquisition, retention of } \\
\text { knowledge and self-confidence } \\
\text { for parenteral medication } \\
\text { administration in nursing } \\
\text { students. }\end{array}$ & $\begin{array}{l}\text { Quasi-experimental } \\
\text { study without } \\
\text { comparison group } \\
\text { Level } 3 \\
\text { SRR }=41(73.21 \%)\end{array}$ & $\begin{array}{l}\text { Students demonstrated a significant improvement in } \\
\text { knowledge about parenteral medication administration } \\
\text { from the pre-test to the post-test ( } \mathrm{p}=0.001) \text {. From the } \\
\text { pre-test to the knowledge retention phase, which occurred } \\
\text { three months after the initial phase, students maintained } \\
\text { a significant improvement in knowledge }(\mathrm{p}=0.001) \text {. } \\
\text { Students were more confident to administer medication } \\
\text { parenterally from the pre-test to the post-test }(\mathrm{p}=0.02) \text { and } \\
\text { to the retention phase }(\mathrm{p}=0.03) \text {. }\end{array}$ \\
\hline
\end{tabular}




\begin{tabular}{|c|c|c|c|}
\hline Title & Objective & $\begin{array}{l}\text { Outlining/Level of } \\
\text { Evidence/SRR }\end{array}$ & Main results \\
\hline $\begin{array}{l}\text { Use of simulation from high } \\
\text { fidelity to low fidelity in } \\
\text { teaching of safe-medication } \\
\text { practices }^{(33)}\end{array}$ & $\begin{array}{l}\text { To assess the effects of } \\
\text { simulation techniques on } \\
\text { learning outcomes in teaching } \\
\text { safe medication administration } \\
\text { to first-year nursing students. }\end{array}$ & $\begin{array}{l}\text { Quasi-experimental } \\
\text { study without } \\
\text { comparison group } \\
\text { Level } 3 \\
\text { SRR }=39(69.64 \%)\end{array}$ & $\begin{array}{l}\text { The total score of students in the post-test was higher than } \\
\text { in the pre-test }(p=0.046) \text {. The performance of students } \\
\text { in safe medication practice scenario was satisfactory. } \\
\text { Satisfaction and self-confidence were also satisfactory after } \\
\text { simulation. }\end{array}$ \\
\hline $\begin{array}{l}\text { The effect of simulation } \\
\text { training on baccalaureate } \\
\text { nursing students' competency } \\
\text { in performing intramuscular } \\
\text { injection }^{(34)}\end{array}$ & $\begin{array}{l}\text { To determine the effect of } \\
\text { simulation training on the } \\
\text { competence of undergraduate } \\
\text { nursing students to administer } \\
\text { intramuscular injections (IM). }\end{array}$ & $\begin{array}{l}\text { Quasi-experimental } \\
\text { study with comparison } \\
\text { group } \\
\text { Level } 3 \\
\text { SRR }=31(55.35 \%)\end{array}$ & $\begin{array}{l}\text { The competence of intramuscular injection of students } \\
\text { who received training in simulation was superior to the } \\
\text { competence of intramuscular injection of students who } \\
\text { did not receive training in simulation. }\end{array}$ \\
\hline $\begin{array}{l}\text { Impact of Simulation- } \\
\text { Enhanced Pharmacology } \\
\text { Education in Prelicensure } \\
\text { Nursing Education }^{(35)}\end{array}$ & $\begin{array}{l}\text { To test the effect of simulation } \\
\text { on undergraduate nursing } \\
\text { students on confidence, } \\
\text { competence and adverse events } \\
\text { in medication administration } \\
\text { practice. }\end{array}$ & $\begin{array}{l}\text { Quasi-experimental } \\
\text { study with comparison } \\
\text { group } \\
\text { Level } 3 \\
\text { SRR }=37(66.07 \%)\end{array}$ & $\begin{array}{l}\text { Improvements in self-reported competence over time } \\
\text { were observed in both groups }(p<0.001) \text {. The control } \\
\text { group (traditional practice) showed a decrease in } \\
\text { self-reported confidence over time }(p<0.001) \text {. Control } \\
\text { group students reported greater post-test competence } \\
\text { compared to the experimental group (simulation) } \\
(p=0.034) \text {. Medication administration at the correct time } \\
(p=0.021) \text { and correct hand hygiene }(p=0.017) \text { were greater } \\
\text { in the experimental group. }\end{array}$ \\
\hline $\begin{array}{l}\text { Using standardized patients } \\
\text { in nursing education: Effects } \\
\text { on students' psychomotor skill } \\
\text { development }^{(36)}\end{array}$ & $\begin{array}{l}\text { To examine the impact using } \\
\text { SP on the development } \\
\text { of skills related to blood } \\
\text { pressure measurement and } \\
\text { administration of subcutaneous } \\
\text { injection among beginning } \\
\text { nursing students. }\end{array}$ & $\begin{array}{l}\text { Quasi-experimental } \\
\text { study with comparison } \\
\text { group } \\
\text { Level } 3 \\
\text { SRR }=38(67.85 \%)\end{array}$ & $\begin{array}{l}\text { The performance scores for administration of } \\
\text { subcutaneous injection were close between the control } \\
\text { (theoretical lecture) and experimental (simulation) groups } \\
\text { ( } p=0.524) \text {. Experimental group students reported that } \\
\text { simulated laboratory practices were effective in improving } \\
\text { the ability to administer subcutaneous injection. Verbal } \\
\text { reports from experimental group students reinforce } \\
\text { that the simulated practice with standardized patients } \\
\text { improved self-confidence. }\end{array}$ \\
\hline $\begin{array}{l}\text { Home care simulation for } \\
\text { student nurses: Medication } \\
\text { management in the home }{ }^{(37)}\end{array}$ & $\begin{array}{l}\text { To assess students' knowledge, } \\
\text { skills and ability to properly } \\
\text { administer medications during } \\
\text { simulated home care. }\end{array}$ & $\begin{array}{l}\text { Quasi-experimental } \\
\text { study with comparison } \\
\text { group } \\
\text { Level } 3 \\
\text { SRR }=42(75.5 \%)\end{array}$ & $\begin{array}{l}\text { Experimental group students (simulation) demonstrated a } \\
\text { significant and more expressive increase in self-confidence } \\
\text { scores perceived from pre to post-simulation ( } p<0.01) \text {. The } \\
\text { experimental }(90 \%) \text { and control (traditional experience) } \\
\text { groups }(82 \%) \text { demonstrated improvement in knowledge, } \\
\text { although the experimental group was superior }(p=0.02) \text {. }\end{array}$ \\
\hline
\end{tabular}

Table 1 - Resources used by the studies to carry out simulation, degree of fidelity of the scenarios employed and characteristics of the medication administration used in the included studies $(n=14)$, Brasília, Federal District, Brazil, 2019

\begin{tabular}{lccc}
\hline Characteristics (n=14) & $\mathbf{n}$ & $\%$ & Studies \\
\hline Resources used in simulation & & & \\
$\quad$ High fidelity mannequin & 5 & 35.7 & $(25),(28),(30),(31),(32)$ \\
$\quad$ Medium fidelity mannequin & 0 & 0.0 & - \\
$\quad$ Low fidelity mannequin & 3 & 21.4 & $(29),(30),(33)$ \\
$\quad$ Standardized patients (role play) & 6 & 42.8 & $(25),(29),(31),(33),(34),(36)$ \\
$\quad$ Virtual reality environment & 2 & 14.3 & $(26),(33)$ \\
$\quad$ Not specified & 4 & 28.6 & $(24),(27),(35),(37)$, \\
$\quad$ Degree of fidelity of scenarios & & & \\
$\quad$ High fidelity scenario & 7 & 50.0 & $(25),(26),(28),(30),(31),(32),(33)$ \\
$\quad$ Medium fidelity scenario & 1 & 7.1 & $(34)$ \\
$\quad$ Low fidelity scenario & 4 & 28.3 & $(29),(30),(33),(34)$ \\
$\quad$ Not specified & 5 & 35.7 & $(24),(27),(35),(36),(37)$ \\
Administration route & & & $(27),(28),(30),(31),(35),(37)$ \\
$\quad$ Oral route & 6 & 42.8 & $(27),(29),(31),(33),(35)$ \\
$\quad$ Intravenous route & 5 & 35.7 & $(27),(31),(33),(34)$ \\
$\quad$ Intramuscular route & 4 & 28.6 & $(30),(31),(33),(35),(36)$ \\
$\quad$ Subcutaneous route & 5 & 35.7 & $(32)$ \\
$\quad$ Inhalation route & 1 & 7.1 & $(24),(25),(26)$ \\
$\quad$ Others & 1 & 7.1 & \\
$\quad$ Not specified & 3 & 21.4 &
\end{tabular}

Of the total of 14 studies reviewed, compared to experimental group students, who experienced teaching based on simulation, only 1 study (7.1\%; Level 3 ) showed that students who experienced a traditional approach (control group) showed better scores in the self-assessment of competence for medication administration $^{(35)}$. Furthermore, another 3 (21.4\%; Level 3) studies did not show differences between the simulation strategy and traditional teaching with regard to the acquired knowledge ${ }^{(24)}$ and the students' practical performance for medication administration $^{(25-26)}$. In this context, 10 other studies (71.4\%) showed that the simulation strategy showed greater effectiveness to develop student skills than the traditional methodology and in this case the level of evidence varied between $3(70 \%)$ and 2 (30\%). 


\section{DISCUSSION}

This study assessed the contribution of low, medium or high fidelity simulation to the learning process. The results confirmed that the realistic simulation employed as a teaching strategy improves knowledge gain; skills and attitudes in safe medication administration for undergraduate nursing students alone or when compared to traditional teaching methodology.

In the world scenario, the publication of the Institute of Medicine (IOM) report was the starting point for discussions about patient safety, based on the great occurrence of adverse events related to health care in the United States. In this report, the occurrence of MS showed great expressiveness and prominence in the scientific community ${ }^{(38)}$.

Surely, inexperienced nurses as well as nursing students have difficulties in safe medication administration; lack of clinical judgment and recognition of problems in the medication process. These conditions can be minimized or suppressed by the teaching and learning process mediated by realistic simulation, an active and innovative strategy ${ }^{(39-40)}$, a finding described in the studies included in this review. Above all, simulation, per se, is a strategy capable of improving patient safety and is still effective in reducing $\mathrm{ME}^{(41)}$. Although most studies highlight the positive effects of simulation for gaining technical and non-technical knowledge and skills, the traditional method is the predominant model in the teaching of Brazilian nursing and has its space until today. Mainly by adopting progressive trends, the traditional school still represents one of the ways of providing learning, considering the different spaces and access to technologies ${ }^{(42)}$.

In a meta-analysis, as well as in the studies of this integrative review, it was possible to identify the effects and significant improvements after implementing simulation-mediated education in several domains of nursing education ${ }^{(43)}$.

Such findings can be supported by the understanding of simulation using mannequins as an effective and innovative didactic method capable of assisting in the teaching and learning process by reproducing a safe and controlled environment, without risks to patient safety that allows students to practice various procedures $^{(44)}$. Therefore, the studies in this review reaffirm this perspective, highlighting the improvement of knowledge, critical thinking and decision making, as a result of simulation.

The students' potential inability to establish a relationship with the mannequin as a real person, especially in the communication and security spectrum, shows an important weakness in the use of patient simulators. However, the alternative emerges from the use of standardized patients, actors sufficiently trained in reproducing patients'signs, symptoms, feelings and generating opportunities in improving communication and self-confidence for safe medication administration ${ }^{(45-46)}$. The impact of simulation on student learning is closely related to the facilitator's competence and experience in guiding reflective discussions, encouraging learners to find the best solutions based on simulated scenarios. Although many advances are apparent, the difficulty of access to technological resources for many professors is still a reality and expresses the need for discussion ${ }^{(47)}$.

In addition to patient simulators (mannequins) and standardized patients (role play), using virtual simulation has been encouraged by adding even more innovation and interactivity, when compared to traditional simulation. Thus, it is characterized by modalities such as screen-based simulation (SBD) and three-dimensional virtual reality (3D-RV). In SBD, the clinical scenario with one or more patients is presented through the digital surface screen and allows interactions through an avatar capable of performing manipulations and procedures. 3D-RV goes beyond the limits of the screen, allowing students to fully immerse themselves in a digital environment ${ }^{(48)}$.

Simulation strategies with virtual reality show advantages over simulation of patients based on dummies, standing out for the possibility of replicability, portability, asynchrony, distribution and data collection. However, the disadvantages of using virtual reality include the high cost and high time of software development, propensity to technical problems and impaired loyalty for some applications that require psychomotor skills ${ }^{(48)}$. Two studies included in this review used SBD and their results indicated that the strategy contributes to the knowledge, satisfaction and self-confidence of nursing students in medication administration ${ }^{(26,33)}$. However, it is recommended to carry out primary studies that compare simulation with virtual reality or other learning strategies in different contexts, in order to verify its applicability in nursing education, especially in safe medication administration.

Medication administration is an activity that can be developed individually. Some authors have adopted scenarios in which students participated individually ${ }^{(24,26,28,32,37)}$, in pairs in $^{(25,34-35)}$ or in groups $^{(27,30)}$. It was not possible to establish, however, if there are differences between the use of individual scenarios or with more than one student in promoting competence in safely administering medications, therefore studies are needed to ascertain this aspect.

\section{Study limitations}

Realistic simulation demonstrates superior results for acquiring knowledge, skills and attitudes in safe medication administration, compared to traditional strategy. But the small number of eligible primary studies demonstrates weakness in generalizing the findings as they include participants in different levels of training in a non-standardized way, configuring the limitations of this review.

\section{Contributions to nursing}

Although using descriptive statistics in some included studies makes it difficult to establish a causal relationship between using simulation and acquiring skills for safe medication administration ${ }^{(25,30,34)}$, and despite the limitations described, this study suggests that simulation-mediated education has a positive influence on nursing students' skills gain in safe medication administration. These results provide relevant scientific data related to implementing simulation in nursing education.

\section{CONCLUSION}

Realistic simulation, as an active and innovative learning methodology, was highlighted in primary studies as a promising strategy for teaching medication administration based on safe practices 
adopted in nursing education. Low and high fidelity simulators, standardized patients and virtual simulation are technological resources capable of contributing to the gain of knowledge, skills and attitudes essential to patient safety. Therefore, they reveal greater easiness to the teaching and learning process in relation to traditional strategies, given the co-responsibility introjected in students during this process.

\section{FUNDING}

This study was carried out with the support of the Coordination for the Improvement of Higher Education Personnel (CAPES - Coordenação de Aperfeiçoamento de Pessoal de Level Superior) - Brazil, through the Social Demand Scholarship granted to the first author during the Academic Master's course.

\section{REFERENCES}

1. Santana BS, Rodrigues BS, Stival Lima MM, Rehem TCMSB, Lima LR, Volpe CRG. Interruptions in the work of nursing as a risk factor for medication errors. Av Enferm. 2019;37(1):56-64. doi: 10.15446/av.enferm.v37n1.71178

2. Reis GAX, Oliveira JLC, Ferreira AMD, Vituri DW, Marcon SS, Matsuda LM. Difficulties to implement patient safety strategies: perspectives of management nurses. Rev Gaúcha Enferm. 2019;40(spe):e20180366. doi: 10.1590/1983-1447.2019.20180366

3. Duarte SCM, Stipp MAC, Silva MM, Oliveira FT. Adverse events and safety in nursing care. Rev Bras Enferm. 2015;68(1):144-54. doi: 10.1590/0034-7167.2015680120p

4. Magalhães AMM, Moura GMSS, Pasin SS, Funcke LB, Pardal BM, Kreling A. The medication process, workload and patient safety in inpatient units. Rev Esc Enferm da USP. 2015;49(spe):43-50. doi: 10.1590/S0080-623420150000700007

5. Alsaidan J, Portlock J, Aljadhey HS, Shebl NA, Franklin BD. Systematic review of the safety of medication use in inpatient, outpatient and primary care settings in the Gulf Cooperation Council countries. Saudi Pharm J. 2018;26(7):977-1011. doi: 10.1016/j.jsps.2018.05.008

6. Caveião C, Zagonel IPS, Coelho ICM, Peres AM, Montezeli JH. Perception of teachers about the learning process in nursing administration. Cogitare Enferm. 2015;20(1):103-11. doi: 10.5380/ce.v20i1.40628

7. Cruz PO, Carvalho TB, Pinheiro LDP, Giovannini PE, Nascimento EGC, Fernandes TAAM. Perception of Effectiveness of the Teaching Methods Used in a Medical Course in Northeast Brazil. Rev Bras Educ Med. 2019;43(2):40-7. doi: 10.1590/1981-52712015v43n2rb20180147

8. Evangelista DL, Ivo OP. Contributions of supervised training of vocational nursing. Rev Enferm Contemp. 2014;3(2):123-30. doi: 10.17267/2317-3378rec.v3i2.391

9. Madalena P, Hermida V, Barbosa SS. Active methodology in nursing education: innovation of the practice in the primary health care. Rev Enferm da UFSM. 2015;5(4):683-91. doi: 10.5902/2179769216920

10. Enderle CF, Silveira RS, Dalmolin GL, Lunardi VL, Avila LI, Dominguez CC. Teaching strategies: promoting the development of moral competence in undergraduate students. Rev Bras Enferm. 2018;71(suppl 4):1650-6. doi: 10.1590/0034-7167-2017-0704

11. Moya EC. Using active methodologies: the student's view. Procedia Soc Behav Sci. 2017;237(2017):672-7. doi: 10.1016/j.sbspro.2017.02.040

12. Presado MHCV, Colaço S, Rafael H, Baixinho CL, Félix I, Saraiva C, et al. Learning with High Fidelity Simulation. Cien Saude Colet. 2018;23(1):51-9. doi: 10.1590/1413-81232018231.23072017

13. Curl ED, Smith S, Ann Chisholm L, McGee LA, Das K. Effectiveness of Integrated Simulation and Clinical Experiences Compared to Traditional Clinical Experiences for Nursing Students. Nurs Educ Perspect [Internet]. 2016 [cited 2019 Nov 23];37(2):72-7. Available from: http://www. ncbi.nlm.nih.gov/pubmed/27209864

14. Martins JCA. Learning and development in simulated practice environments. Rev Enferm Ref. 2017;vol.serIV:155-62. doi: 10.12707/RIV16074

15. Campoe KR, Giuliano KK. Impact of frequent interruption on nurses' patient-controlled analgesia programming performance. Hum Factors. 2017;59(8):1204-13. doi: 10.1177/0018720817732605

16. Flannery AH, Parli SE. Medication errors in cardiopulmonary arrest and code-related situations. Am J Crit Care. 2016;25(1):12-20. doi: $10.4037 /$ ajcc2016190

17. Whittemore R, Knafl K. The integrative review: updated methodology. J Adv Nurs. 2005;52(5):546-53. doi: 10.1111/j.1365-2648.2005.03621.x

18. Santos CMDC, Pimenta CADM, Nobre MRC. The PICO strategy for the research question construction and evidence search. Rev Latino-Am Enfermagem. 2007;15(3):508-11. doi: 10.1590/S0104-11692007000300023

19. Krüger LM, Ensslin SR. The Traditional Teaching Method and the Constructivist one in the teaching and learning process: an investigation into the reactions of the students of Accounting III, a subject of the undergraduate Accounting Course at the Federal University of Santa Cat. Rev Organ Context. 2013;9(18):219-70. doi: 10.15603/1982-8756/roc.v9n18p219-270

20. Santos JLG, Souza CSBN, Tourinho FSV, Sebold LF, Kempfer SS, Linch GFC. Didatic strategies in thte teaching-learning process of nursing manegement. Texto Contexto Enferm. 2018;27(2):1-11. doi: 10.1590/0104-070720180001980016

21. Oxford Centre for Evidence-Based Medicine. OCEBM Levels of Evidence Working Group. The Oxford 2011 Levels of Evidence [Internet]. Oxford Centre for Evidence-Based Medicine. 2011 [cited 2019 Nov 26]. Available from: http://www.cebm.net/index.aspx?o=5653

22. Fey MK, Gloe D, Mariani B. Assessing the quality of simulation-based research articles: a rating rubric. Clin Simul Nurs. $2015 ; 11$ (12):496-504. doi: 10.1016/j.ecns.2015.10.005 
23. Horsley TL, O'Rourke J, Mariani B, Doolen J, Pariseault C. An integrative review of interprofessional simulation in nursing education. Clin Simul Nurs. 2018;22:5-12. doi: 10.1016/j.ecns.2018.06.001

24. Avraham R, Shor V, Hurvitz N, Shvartsur R, Kimhi E. Transferability of medication administration simulation training to clinical settings. Teach Learn Nurs. 2018;13(4):258-62. doi: 10.1016/j.teln.2018.07.004

25. Campbell CA. Impact of simulation on safe medication practice with diploma/ADN students. Teach Learn Nurs. 2013;8(4):147-56. doi: 10.1016/j.teln.2013.07.004

26. Dubovi I, Levy ST, Dagan E. Now I know how! the learning process of medication administration among nursing students with nonimmersive desktop virtual reality simulation. Comput Educ. 2017;113:16-27. doi: 10.1016/j.compedu.2017.05.009

27. Harris MA, Pittiglio L, Newton SE, Moore G. Using Simulation to Improve the Medication Administration Skills of Undergraduate Nursing Students. Nurs Educ Perspect. 2014;35(1):26-9. doi: 10.5480/11-552.1

28. Jarvill M, Jenkins S, Akman O, Astroth KS, Pohl C, Jacobs PJ. Effect of Simulation on Nursing Students' Medication Administration Competence. Clin Simul Nurs. 2018;14:3-7. doi: 10.1016/j.ecns.2017.08.001

29. Kelly SH, Koharchik L, Henry R, Cippel M, Hardner S, Kolesar A, et al. An Advanced medication administration experience to promote students' knowledge acquisition in the skill of administering medications. Teach Learn Nurs. 2018;13(2):104-7. doi: 10.1016/j. teln.2017.12.002

30. Konieczny L. Using high-fidelity simulation to increase nursing student knowledge in medication administration. Teach Learn Nurs. 2016;11(4):199-203. doi: 10.1016/j.teln.2016.08.003

31. Mariani B, Ross JG, Paparella S, Allen LR. Medication safety simulation to assess student knowledge and competence. Clin Simul Nurs. 2017;13(5):210-6. doi: 10.1016/j.ecns.2017.01.003

32. Nascimento MS, Magro MCS. Realistic simulation: method of improving knowledge and self-confidence of nursing students in the administration of medication. Rev Min Enferm. 2018;22:1-5. doi: 10.5935/1415-2762.20180024

33. Onturk ZK, Ugur E, Kocatepe V, Ates E, Ocaktan N, Unver V, et al. Use of simulation from high fidelity to low fidelity in teaching of safemedication practices. J Pak Med Assoc [Internet]. 2019 [cited 2019 Nov 26];69(2):195-200. Available from: https://www.ncbi.nlm.nih.gov/ pubmed/30804583

34. Ross JG. The effect of simulation training on baccalaureate nursing students' competency in performing intramuscular injection. Nurs Educ Perspect. 2015;36(1):48-9. doi: 10.5480/13-1075.1

35. Sanko JS, Mckay M. Impact of simulation-enhanced pharmacology education in prelicensure nursing education. Nurse Educ. 2017;42(Sup1):S32-7. doi: 10.1097/NNE.0000000000000409

36. Sarmasoglu S, Dinç L, Elçin M. Using standardized patients in nursing education: effects on students' psychomotor skill development. Nurse Educ. 2016;41(2):E1-5. doi: 10.1097/NNE.0000000000000188

37. Mager DR, Campbell SH. Home care simulation for student nurses: Medication management in the home. Nurse Educ Today. 2013;33(11):1416-21. doi: 10.1016/j.nedt.2012.11.007

38. Kohn LT, Corrigan JM, Donaldson MS. To Err Is Human: building a safer health system [Internet]. 1st ed. Washington, D.C.: Committee on Quality of Health Care in America; 2000. 287 p. doi: 10.17226/9728

39. Whitehair L, Provost S, Hurley J. Identification of prescribing errors by pre-registration student nurses: A cross-sectional observational study utilising a prescription medication quiz. Nurse Educ Today. 2014;34(2):225-32. doi: 10.1016/j.nedt.2012.12.010

40. Schneidereith TA. Using Simulations To Identify Nursing Student Behaviors: A Longitudinal Study of Medication Administration. J Nurs Educ. 2014;53(2):89-92. doi: 10.3928/01484834-20140122-07

41. Zimmerman DM, House P. Medication Safety: Simulation Education for New RNs Promises an Excellent Return on Investment. Nurs Econ [Internet]. 2016 [cited 2019 Nov 26];34(1):49-51. Available from: http://www.ncbi.nlm.nih.gov/pubmed/27055312

42. Lazzari DD, Pedro ENR, Sanches MO, Jung W. Estratégias de ensino do cuidado em enfermagem: um olhar sobre as tendências pedagógicas. Rev Gaúcha Enferm. 2011;32(4):688-94. doi: 10.1590/\$1983-14472011000400008

43. Shin S, Park J-H, Kim J-H. Effectiveness of patient simulation in nursing education: Meta-analysis. Nurse Educ Today. 2015;35(1):176-82. doi: 10.1016/j.nedt.2014.09.009

44. Jesus BC, Ramos GF, Silva CCR, Gomes VCO, Silva GTR. Simulation with mannequins as a learning-teaching strategy for wound care assessment: an experience report. Rev Estima. 2017;15(4):245-9. doi: 10.5327/Z1806-3144201700040009

45. Ham KL. Use of standardized patients to enhance simulation of medication administration. Nurse Educ [Internet]. 2016 [cited 2019 Nov 26];41(4):166-8. doi: 10.1097/NNE.0000000000000248

46. Beischel KP, Hart J, Turkelson S, Churchill J. Using a standardized patient to teach fall safety. Clin Simul Nurs. 2014;10(4):e183-90. doi: 10.1016/j.ecns.2013.11.007

47. Kaneko RMU, Lopes MHB de M. Realistic health care simulation scenario: what is relevant for its design? Rev Esc Enferm USP. 2019;53:e03453. doi: 10.1590/s1980-220x2018015703453

48. Chang TP, Weiner D. Screen-Based Simulation and Virtual Reality for Pediatric Emergency Medicine. Clin Pediatr Emerg Med. 2016;17(3):22430. doi: 10.1016/j.cpem.2016.05.002 